\title{
The effect of variety, supplementation with tryptophan, dehulling and autoclaving on utilization of field bean (Vicia faba L.) seeds by broiler chickens
}

\section{Stefania Smulikowska and Małgorzata Chibowska}

The Kielanowski Institute of Animal Physiology and Nutrition, Polish Academy of Sciences 05-110 Jablonna, Poland

(Received 28 September 1993; accepted 19 October 1993)

\section{ABSTRACT}

During 21 days experiment on 110,8-day-old Astra B male chicks, two varieties of field bean (FB): Nadwiślański and Dino were compared with soya bean oil meal as a source of supplementary protein in wheat-triticale diets. The isocaloric, isoprotein and fortified with DL-methionine diets contained $30 \%$ of FB seeds were fed unsupplemented or supplemented with $0.2 \mathrm{~g} \mathrm{~L}$-tryptophan per $\mathrm{kg}$.

The $\mathrm{AME}_{\mathrm{N}}$ of raw seeds of both $\mathrm{FB}$ varieties and of $\mathrm{FB}$ var. Dino processed in different ways (raw, dehulled, autoclaved, autoclaved and dehulled) was determined on 4-week-old cockerels.

The seeds of both varieties of FB, fortified with methionine, were as effective as soya bean oil meal as a supplementary protein source in wheat-triticle diets. Supplementation with tryptophan had no positive effect on chick performance.

The $\mathrm{AME}_{\mathrm{N}}$ of FB var. Dino was lower than of FB var. Nadwiślański (11.0 vs $11.4 \mathrm{~kJ} / \mathrm{g} \mathrm{DM}$, respectively). After autoclaving, the $\mathrm{AME}_{\mathrm{N}}$ of $\mathrm{FB}$ var. Dino increased by $7 \%$, after dehulling by $15 \%$.

KEY WORDS: field bean, broiler chicken, dehulling, heating, metabolizable energy

\section{INTRODUCTION}

The high lysine content of the field bean (Vicia faba L.) protein makes it a good supplement to the cereal protein in poultry feeds. The first amino acid that limits the biological value of field bean protein is methionine, followed by tryptophan (Eggum, 1980; Pastuszewska et al., 1978). A deficit of these amino acids may thus be expected in mixtures of field beans with wheat and triticale.

The nutritional value of FB seeds also depends on the susceptibility of its protein and carbohydrates to enzymatic digestion and on the presence of antinutrients - tannins, lectins, trypsin inhibitors and phytic acid - that may 
interfere with digestion and metabolism (Carnovale et al., 1988; Eggum, 1980; Ernest, 1987; Pastuszewska, 1985; Rubio et al., 1989). Tannins are concentrated mainly in the hulls of FB seeds, while the concentration of trypsin inhibitors and lectins is higher in cotyledons. The hulls comprises from 13 to $15 \%$ of the seed (Eggum, 1980; Pastuszewska, 1985).

The apparent metabolizable energy value $\left(\mathrm{AME}_{\mathrm{N}}\right)$ of $\mathrm{FB}$ seeds for poultry equals approximately $11 \mathrm{MJ} / \mathrm{kg} \mathrm{DM}$ and is higher than that of soya bean meal but lower than that of wheat and triticale. The metabolizable energy of FB seeds increases due to dehulling (Longstaff et al., 1991) and autoclaving (Guillaume, 1973; Ryś and Fraś, 1980).

The aim of the study was to compare the Polish standard FB variety Nadwiślański and a newer variety, Dino, as energy and protein sources for broiler chicks and to evaluate the effect of dehulling and autoclaving on the metabolizable energy of FB seeds of var. Dino.

\section{MATERIAL AND METHODS}

Raw field bean seeds Nadwiślański and Dino from the 1988 harvest and Dino from the 1989 harvest - unprocessed, dehulled, autoclaved (heated for $10 \mathrm{~min}$. in an autoclave at $100^{\circ} \mathrm{C}$ ) or autoclaved and dehulled were used in the experiments. The samples of FB were obtained from the region of Olsztyn.

The basic chemical composition and fibre content of all the seeds were determined by conventional methods. Their amino acid composition was determined using a Beckman amino acid analyser. Methionine and cystine were assayed after oxidation with performic acid, tryptophan after hydrolysis with barium hydroxide. Trypsin inhibitor activity (Kakade et al., 1974) and tannin content (Adams and Novellie, 1975) were determined in raw and processed seeds var. Dino, 1989.

\section{Experiment 1}

FB seeds var. Nadwiślański and Dino from the 1988 harvest were compared as sources of supplementary protein, partially replacing soya bean oil meal protein in wheat-triticale diets.

The experiment was conducted on 110, 8-day-old Astra B broiler cockerels with the average initial weight of $101 \pm 5 \mathrm{~g}$. The birds were housed in pairs in cages equipped with heaters and feed and water supply. One group comprised 11 pairs of birds.

The cockerels were fed the experimental diets (Table 4) to appetite for 3 weeks. Body weight and feed consumption were measured weekly and the body weight gain and feed utilization were calculated for each pair of birds. The significance of the differences among the groups was assessed using Duncan's multiple range test. 


$$
\begin{aligned}
& \text { 站 }
\end{aligned}
$$

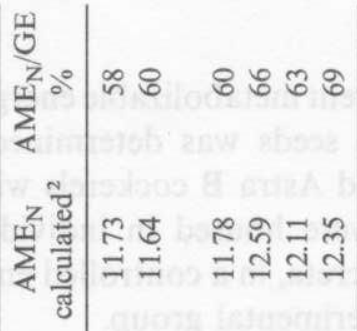

$$
\begin{aligned}
& \text { चु. } \\
& \text { ฐ్ }
\end{aligned}
$$

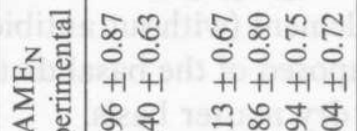

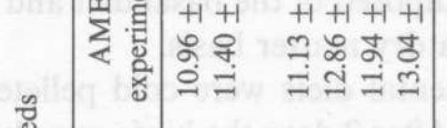

$$
\begin{aligned}
& \text { 몽 }
\end{aligned}
$$

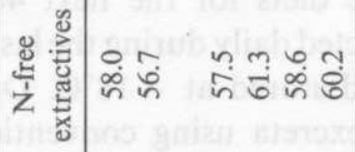

$$
\begin{aligned}
& \sum_{0} \\
& \frac{\infty}{3}
\end{aligned}
$$

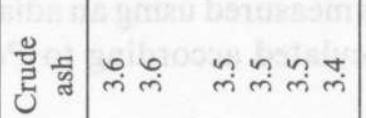

$$
\begin{aligned}
& \text { 递 } \\
& \text { 红 总 } \\
& \text { बें }
\end{aligned}
$$




\section{Experiment 2}

The $\mathrm{AME}_{\mathrm{N}}$ value - apparent metabolizable energy corrected for zero nitrogen balance - of the evaluated seeds was determined in 2 balance experiments conducted on 80,4-week-old Astra B cockerels with the average body weight about $760 \mathrm{~g}$. The chicks were housed in individual cages equipped for the quantitative collection of excreta, in a controlled environment with $24 \mathrm{~h} \mathrm{light} / \mathrm{d}$. 10 birds constituted an experimental group.

Basal diet was composed of $(\mathrm{g} / \mathrm{kg})$ : ground wheat 695 , soya bean oil meal 266 and a vitamin-mineral supplement (without antibiotics or methionine) 39 . The experimental diets were composed of the basal diet and finely ground FB seeds mixed in a $60: 40$ ratio on a dry matter basis.

The basal and experimental diets were cold pelleted, $100 \mathrm{~g} / \mathrm{per}$ bird were offered daily in 3 portions. After 2 days the birds were kept fasting for $24 \mathrm{~h}$, and then were offered the same diets for the next $48 \mathrm{~h}$. Feed consumption was measured, excreta were collected daily during the last $48 \mathrm{~h}$ and $24 \mathrm{~h}$ of consecutive fast, frozen immediately and stored at $-18^{\circ} \mathrm{C}$. Dry matter and total $\mathrm{N}$ were determined in lyophylised excreta using conventional methods, gross energy value of feed and excreta was measured using an adiabatic bomb calorimeter. The $\mathrm{AME}_{\mathrm{N}}$ of the seeds was calculated according to Pesti and Ware (1986).

TABLE 2

Content of tannin, trypsin inhibitor and dietary fibre in field bean var. Dino (1989) - raw and processed (in \% DM)

\begin{tabular}{lrccc}
\hline Component & Raw & Raw dehulled & Autoclaved & $\begin{array}{c}\text { Autoclaved } \\
\text { dehulled }\end{array}$ \\
\hline Tannis & & & & 0.66 \\
Trypsin inhibitor & 0.83 & 0.24 & 3.29 & 0.37 \\
TIU/mg protein & 16.67 & 17.48 & 6.61 & 4.02 \\
Crude fibre & 8.41 & 2.32 & 11.00 & 6.46 \\
ADF & 11.75 & 3.42 & 11.18 & 8.70 \\
NDF & 15.02 & 6.28 & 1.29 & 0.75 \\
ADL & 1.39 & 0.35 & & \\
\hline
\end{tabular}

${ }^{1}$ equivalent of tannic acid

RESULTS AND DISCUSSION

Both FB varieties contained approximately $29 \%$ protein on a dry matter basis (Table 1). The amino acid composition of the protein from both FB varieties, given in Table 3, was similar to that reported by Pastuszewska (1985) and Eggum (1980). In comparison with soya bean protein, the protein of field bean had higher 
lysine and arginine content and lower sulphur-containing amino acids and tryptophan content. Comparison of the varieties showed that the FB Nadwiślanski had slightly more sulphur-containing amino acids ( 2.35 vs 2.21 ) while the FB Dino had more tryptophan (1.04 vs 0.97$)$ and lysine (6.34 vs $6.26 \mathrm{~g} / 16 \mathrm{gN})$.

TABLE 3

Amino acid composition of field bean protein $(\mathrm{g} / 16 \mathrm{~g} \mathrm{~N})$

\begin{tabular}{lcccccc}
\hline Amino acid & Nadwiślański & Dino & \multicolumn{4}{c}{ Dino, 1989 } \\
\cline { 5 - 7 } & 1988 & 1988 & raw & raw dehulled & autoclaved & $\begin{array}{c}\text { auoclaved } \\
\text { dehulled }\end{array}$ \\
\hline Lys & 6.26 & 6.34 & 6.36 & 6.45 & 6.34 & 6.43 \\
Lys available & - & - & 5.78 & 5.87 & 5.77 & 5.86 \\
Cys & 1.36 & 1.26 & 1.22 & 1.21 & 1.22 & 1.21 \\
Met & 0.99 & 0.95 & 0.73 & 0.77 & 0.74 & 0.75 \\
Thr & 3.65 & 3.72 & 3.81 & 3.83 & 3.81 & 3.86 \\
Try & 0.97 & 1.04 & 1.04 & 0.96 & 1.04 & 1.00 \\
Arg & 9.95 & 9.72 & 10.38 & 10.78 & 10.73 & 10.50 \\
\hline
\end{tabular}

The small differences in the amino acid content between the varieties were not reflected in the results of the experiment 1 (Table 5). No differences were found either between the experimental groups and control (soya bean) group. Supplementation of the diets with tryptophan had no effect on performance or feed utilization. The level of lysine and threonine in the diets containing field beans (Table 4) somewhat exceeded the requirements of broiler chicks of this age. This, in conjunction with no reaction to tryptophan supplementation, indicates that after supplementation with methionine, field bean protein has similar nutritional value in mixed feeds as soya bean oil meal protein. This is in agreement with the observation of Eggum (1980) and the authors cited therein.

The $\mathrm{AME}_{\mathrm{N}}$ of FB Nadwiślański was somewhat higher than that of FB Dino (Table 1).

Dehulling of Dino seeds resulted in the removal of a significant proportion of both tannins and fiber (Table 2 ). The dehulled seeds had an approximately $15 \%$ higher energy value than raw seeds and its gross energy utilization increased by about $10 \%$. It seems that this should be attributed more to the changes in the chemical composition of the dehulled fraction which, in comparison with whole seeds contained more protein and nitrogen-free extractives and less fibre, than to the decrease in the tannin concentration. Longstaff and McNab (1991) observed a decrease in the activity of lipase and $\alpha$-amylase in the content of the duodenum and small intestine of chick as the level of FB hulls in the diet arose, but only when the proportion of hulls reached $30 \%$ did the digestibilities of fat and starch decreased. Both, in the study cited above and in the report by Longstaff et al. 
(1991), cotyledon fractions and hulls from FB of various varieties were mixed in different proportions. $\mathrm{TME}_{\mathrm{N}}$ of these compositions was determined and found to decrease proportionately to the percentage of hulls in the mix. This indicates that the energy of FB hulls is not utilized by chickens.

TABLE 4

Composition of the diets in experiment $1(\mathrm{~g} / \mathrm{kg})$

\begin{tabular}{|c|c|c|c|c|c|}
\hline \multirow[t]{2}{*}{ Ingredients } & \multirow[t]{2}{*}{ Control } & \multicolumn{2}{|c|}{ Dino 1988} & \multicolumn{2}{|c|}{ Nadwiślański 1988} \\
\hline & & unsupplemented & $+\operatorname{Trp}$ & unsupplemented & $+\operatorname{Trp}$ \\
\hline Ground field bean seeds & - & 300 & 300 & 300 & 300 \\
\hline Ground $\operatorname{corn}{ }^{1}$ & 686 & 532 & 532 & 532 & 532 \\
\hline Soya bean oil meal & 270 & 124 & 123.8 & 124 & 123.74 \\
\hline Constant components ${ }^{2}$ & 44 & 44 & 44 & 44 & 44 \\
\hline Tryptophane $^{3}$ & - & - & 0.2 & & 0.26 \\
\hline \multicolumn{6}{|l|}{ Calculated } \\
\hline $\mathrm{AME}_{\mathrm{N}}, \mathrm{MJ} / \mathrm{kg}$ & 10.98 & 10.64 & 10.64 & 10.76 & 10.76 \\
\hline Crude protein, \% & 18.73 & 18.64 & 18.64 & 18.73 & 18.73 \\
\hline Lys, \% & 0.94 & 0.98 & 0.98 & 0.98 & 0.98 \\
\hline Met + cyc, $\%$ & 0.79 & 0.69 & 0.69 & 0.70 & 0.70 \\
\hline Try, \% & 0.24 & 0.22 & 0.24 & 0.214 & 0.24 \\
\hline Thr, \% & 0.62 & 0.64 & 0.64 & 0.64 & 0.64 \\
\hline
\end{tabular}

${ }^{1}$ triticale and wheat (1:1)

${ }^{2}$ limestone $14 \mathrm{~g}$, dicalcium phosphate $16 \mathrm{~g}, \mathrm{NaCl} 4 \mathrm{~g}$, DL-methionine $1 \mathrm{~g}$, vit. A 8000 IU vit. $\mathrm{D}_{3} 1200$ IU, vit. E $10 \mathrm{mg}$, vit. $\mathrm{K} 2 \mathrm{mg}$, vit. $\mathrm{B}_{2} 4 \mathrm{mg}$, vit. $\mathrm{B}_{6} 4 \mathrm{mg}$, vit. $\mathrm{B}_{12} 0.015 \mathrm{mg}$, nicotinic acid $12 \mathrm{mg}, \mathrm{Ca}$ pantothenate $8 \mathrm{mg}$, folic acid $0.2 \mathrm{mg}$, choline $\mathrm{Cl} 150 \mathrm{mg}$, Mn $50 \mathrm{mg}, \mathrm{J} 0.3 \mathrm{mg}, \mathrm{Zn} 30 \mathrm{mg}$, Se $0.1 \mathrm{mg}$, Co $0.4 \mathrm{mg}$

${ }^{3}$ in unsupplemented diets equivalent amount of wheat starch was added

TABLE 5

Results of experiment 1 (average from 3 weeks)

\begin{tabular}{lccccc}
\hline Item & Control & \multicolumn{2}{c}{ Dino 1988 } & \multicolumn{2}{c}{ Nadwislanski 1988 } \\
\cline { 3 - 6 } & & unsupplemented & $\begin{array}{r}0.2 \\
\text { Trp }\end{array}$ & unsupplemented $\begin{array}{r}+0.2 \\
\text { Trp }\end{array}$ \\
\hline $\begin{array}{l}\text { Body weight gain, } \mathrm{g} \\
\begin{array}{l}\text { Feed conversion ratio, } \\
\text { g feed/g gain }\end{array}\end{array}$ & 614 & 614 & 618 & 618 & 580 \\
\hline
\end{tabular}

differences between groups statistically not significant $(P \leqslant 0.05)$

Autoclaving field bean seeds for $10 \mathrm{~min}$ at $100^{\circ} \mathrm{C}$ reduced the activity of trypsin inhibitors by $80 \%$, as well as the tannin and NDF content (Table 2), leading to a $7 \%$ rise in the energy value of the seeds and a $5 \%$ increase in gross 
energy utilization. These results agree with those of Ryś nad Fraś (1980) who determined the ME of unprocessed FB seeds var. Major to equal $11.89 \mathrm{~kJ} / \mathrm{g}$ and of autoclaved $-12.64 \mathrm{~kJ} / \mathrm{g}$, which is $6 \%$ higher. Guillaume (1973) found even a $12 \%$ rise (from 12.98 to $14.65 \mathrm{~kJ} / \mathrm{g}$ ) in the ME of $\mathrm{FB}$ seeds after autoclaving.

Removing a significant part of the hulls from autoclaved seeds increased their metabolizable energy value by $9 \%$. Application of both processes (autoclaving and dehulling) gave a product with an energy value close to that of cereal grain and gross energy utilization improved by $15 \%$.

Partial removal or inactivation of factors having an unfavourable effect on digestion gave a somewhat better result than could be expected from just changes in chemical composition (Table 1). However, as Eggum (1980) emphasizes, improved utilization of field bean seeds by dehulling and autoclaving does not compensate the financial costs of processing.

\section{Acknowledgments}

The authors express appreciation to prof. H. Kozłowska, Centre of Agrotechnology and Veterinary Sciences, Polish Academy of Sciences, Olsztyn, for providing the raw and processed seeds var. Dino.

\section{REFERENCES}

Adams C.A., Novellie K., 1975. Composition and structure of protein bodies and spherosomes isolated from ungerminated seeds of Sorghum bicolor (Linn). Moench. Plant Physiol. 55, 1-6

Carnovale E., Lugaro E., Lombardi-Boccia G., 1988. Phytic acid in faba bean and pea: effect on protein availability. Cereal Chem. 65, 114-117

Eggum B.O., 1980. Factors affecting the nutritional value of field beans (Vicia faba). In: Vicia faba. Feeding value, Processing and Viruses. ed. D.A. Bond, Brussels-Luxemburg, 107-123

Ernest T., 1987. Wplyw tanin z bobiku na strawność dawki i aktywność enzymów przewodu pokarmowego kurcząt. Rocz. Nauk. Zoot. Mon. Rozpr. 25, 205-219

European Table of Energy Value for Poultry Feedstuffs. 1986. Publ. Group No 2 Nutrition, Europ. Fed. WPSA, Wageningen

Guillaume P.J., 1973. Nutritive value of Vicia faba to growing chickens: effect of cooking on availability of nicotinamide. Cachiers Nutr. Diet. 8, 330-337

Kakade M.L., Rackis J.J., McGhee J.E., Puski G., 1974. Determination of trypsin inhibitor activity of soya products: Collaborative analysis of an improved procedure. Cereal Chem. 51, 376-382

Longstaff M.A., McBain B., McNab J.M., 1991. The antinutritive effect of proanthocyanidin-rich and proanthocyanidin-free hulls from field beans on digestion of nutrients and metabolizable energy in intact and caecectomised cockerels. Anim. Feed Sci. Tech. 34, 147161

Longstaff M.A., McNab J.M., 1991. The effect of concentration of tannin-rich bean hulls (Vicia faba L.) on activities of lipase (EC 3.1.1.3.) and $\alpha$-amylase (EC 3.2.1.1.) in digesta and pancreas and on the digestion of lipid and starch by young chicks. Br. J. Nutr. 66, 139-147

Pastuszewska B., 1985. Czynniki wpływające na wartość pokarmową bobiku, grochu i lubinu dla zwierząt nieprzeżuwających. IFiŻZ, Jabłonna

Pastuszewska B., Smulikowska S., Buraczewski S., 1978. Factors affecting the nutritional value of 
field bean protein. Part 3. The second limiting amino acid and the complementary value of field bean given with different low-protein feeds. Rocz. Nauk rol. Ser. B 98, 4, 7-15

Pesti G.M., Ware G.O., 1986. Expressing the variability in results of metabolizable energy assays. J. Nutr. 116, 1385-1389

Rubio L.A., Brenes A., Castano M., 1989. Histological alterations to the pancreas and the intestinal tract produced by raw faba bean (Vicia faba L. minor) diets in growing chicks. Br. Poult. Sci. 30, 101-104

Ryś R., Fraś B., 1980. Energia metaboliczna nasion nowych odmian roślin gruboziarnistych i wpływ parowania na jej wartość. Acta agr. silv. Ser. Zoot. 19, 177-187

\section{STRESZCZENIE}

Wplyw odmiany, uzupełniania tryptofanem, obłuszczania i ogrzewania na wykorzystanie nasion bobiku (Vicia faba L.) przez kurczęta

W trwającym 21 dni doświadczeniu na 110, 8-dniowych kogutkach Astra B porównywano wartość uzupełniającą dwóch odmian bobiku i śruty sojowej w dietach zawierających pszenicę i pszenżyto. Do diet wprowadzono $30 \%$ bobiku, zawartość białka, energii i metioniny wyrównywano do poziomu diety kontrolnej. Diety zawierające bobik podawano nieuzupelnione lub uzupełnione $0,2 \mathrm{~g}$ L-tryptofanu na $\mathrm{kg}$.

$\mathrm{AME}_{\mathrm{N}}$ nasion odmian Nadwiślański i Dino ze zbiorów 1988 roku oraz nasion odmiany Dino ze zbiorów 1989 roku - surowych, obłuszczonych, ogrzewanych, ogrzewanych i obłuszczonych - oznaczano na 4-tygodniowych kogutkach brojlerach.

Obie odmiany bobiku po uzupełnieniu metioniną miały wartość porównywalną ze śrutą sojową jako źródło białka uzupełniającego w diecie pszenno-pszenżytniej. Uzupełnienie tryptofanem nie wpłynęło dodatnio na przyrosty kurcząt ani na wykorzystanie paszy. AME $\mathrm{N}_{\mathrm{N}}$ bobiku odmiany Dino była nieco mniejsza niż odmiany Nadwiślański (11,0 vs 11,4 kJ/g SM). Ogrzewanie zwiększyło AME $_{\mathrm{N}}$ odmiany Dino o $7 \%$, obłuszczanie o $15 \%$. 